\title{
The Implementation of Emergency Aid as an exceptional measure of social protection
}

\section{Bruno Baranda Cardoso ${ }^{1}$}

${ }^{1}$ Ministério da Cidadania, Brasília / DF - Brazil

Emergency Aid, instituted by Law 13982, of 2020, is one of the biggest initiatives of the Brazilin Federal Government to minimize the economic effects of the COVID-19 pandemic. This aid is directed at the most vulnerable population, among them, the beneficiaries of the conditional cash transfer program "Bolsa Família" (PBF) and those enrolled in the single registry for social protection "Cadastro Único para Programas Sociais do Governo Federal" (CadÚnico). The benefit also covers informal employees, self-employed and individual microentrepreneurs (MEI). Based on documentary analysis and through direct observation, this study sought to outline the process of implementing emergency aid measures, within the framework established by the Ministry of Citizenship (MC), through the system-level bureaucracy approach.

Keywords: COVID-19; emergency aid; system-level bureaucracy; Cadastro Único; public policy implementation.

\section{A implementação do Auxílio Emergencial como medida excepcional de proteção social}

O Auxílio Emergencial, instituído pela Lei n 13.982, de 2020, é uma das maiores iniciativas do Governo Federal para minimizar os efeitos econômicos da pandemia do coronavírus (COVID-19) para a parte mais vulnerável da população, entres eles os beneficiários do Programa Bolsa Família (PBF) e os inscritos no Cadastro Único para Programas Sociais do Governo Federal (CadÚnico), cidadãos que já tinham algum tipo de relacionamento com políticas de assistência social. Além desses, o benefício abrange também trabalhadores informais, autônomos e microempreendedores individuais (MEI). Com base na análise documental e por meio de observação direta, este estudo buscou delinear o processo de implementação do Auxílio Emergencial, no âmbito do arranjo estabelecido pelo Ministério da Cidadania (MC), através da abordagem da burocracia de nível de sistema.

Palavras-chave: COVID-19; auxílio emergencial; burocracia de nível de sistema; Cadastro Único; implementação de políticas públicas.

\section{La implementación de la Ayuda de Emergencia como medida excepcional de protección social}

La Ayuda de Emergencia, instituida por la Ley n. 13.982, de 2020, es una de las mayores iniciativas del Gobierno Federal Brasileño para minimizar los efectos económicos de la pandemia de coronavirus (COVID-19) para la parte más vulnerables de la población, entre ellas, los beneficiarios del "Programa Bolsa Família" (PBF) y aquellos inscritos en el Registro Único para Programas Sociales del Gobierno Federal” (CadÚnico), ciudadanos que ya tenían algún tipo de relación con las políticas de asistencia social. Además de estos, el beneficio también abarca a trabajadores informales, autónomos e microempresarios individuales (MEI). Basado en el análisis documental y a través de la observación directa, este estudio buscó esbozar el proceso de implementación de la Ayuda de Emergencia, en el marco establecido por el Ministerio de Ciudadanía (MC), a través del enfoque de burocracia a nivel de sistema.

Palabras clave: COVID-19; ayuda de emergencia; burocracia a nivel de sistema; Cadastro Único; implementación de políticas públicas. 


\section{INTRODUCTION}

Among the measures adopted to combat the coronavirus pandemic (COVID-19), the one that has stood out to minimize the social effects of the restrictive measures and social distancing has been the creation of the Emergency Aid instituted by Law 13982 of 2020.

The Emergency Aid created by this law is a mixture of Basic Income for Good Citizenship, created by Law 10835 of 2004 and the Unemployment Insurance Program instituted by Law 7998 of 1990, though the former was never regulated by the federal government and the latter has dealt strictly with unemployed formal workers who fulfill some requirements. This new aid covers a gap in the social protection of so-called informal workers as long as they meet the conditions stipulated by the law.

Implementing the benefit has its particular characteristics, however, which will be explored in this article and mainly have to do with complying with the institutional configuration which supports the conduct of federal government policy, strategies to identify the target public, and the implementation of Emergency Aid.

The article presents the experiences of implementing Emergency Aid, oriented by the literature of public policy. The public policy cycle is subdivided into five stages: assembling the agenda, formulating policy, making policy decisions, implementing the policy, and evaluating the policy (Howlett, Ramesh, \& Perl, 2013). The focus of this article, therefore, is the stage of implementation. The focus of our analysis within the context of the public policy cycle will be on implementation, or in other words, the moment when a created policy is put into practice.

To do this, the analysis will use the concept of public action arrangements and instruments, in order to identify the actors responsible for the implementation and how the form of action and preexisting relationships influence the singular characteristics of the implementations of this benefit.

The urgency to adopt solutions allied with restrictive measures and social distancing was decisive in the use of ICT (information and communication technology) solutions in the implementation of Emergency Aid. To analyze this experience, we have used street-level and system-level bureaucracy approaches.

\section{THE CONFORMITY OF THE EMERGENCY AID'S INSTITUTIONAL ARRANGEMENT WITHIN THE FEDERAL GOVERNMENT}

With the publication of Decree 10316 of 2020, we can identify the definition of the responsibility of several governmental agencies in the implementation of Emergency Aid, because the internal articulation to make inputs viable for the identification of the target public precedes this act.

The first measure announced by the government which signaled the creation of Emergency Aid by the Ministry of Economy on March 18, 2020 which was later formalized by Law 13982.

It is important to point out that, at the time, restrictive measures and social distancing had already been decreed in most Brazilian states to confront this public health emergency. This fact greatly increased the complexity of implementing the policy and operationalizing the payment of aid, as will be seen below.

Decree 10316 of 2020, in article 4, established that it was the responsibility of the Ministry of Citizenship to "manage the emergency aid for all beneficiaries" and that of the Ministry of Economy to "act jointly with the Ministry of Citizenship (MC) to identify criteria to identify the beneficiaries of emergency aid." 
In this manner, it was established that the Ministry of Citizenship would lead the implementation of the Emergency Aid, without distinction in terms of the target public. However, other actors which were essential to the implementation of the policy were notably absent: Federal Savings Bank (CEF) and the Social Security Information Technology Company (Dataprev). The absence of these government agencies would make it impossible to identify the institutional arrangement established for the implementation of the benefit.

To understand the implementation of public policy, it is important to understand the State not as a single actor, but as an environment within which there are interactions between various agents which play important roles and perform various actions in the everyday production of public policy, in contrast to an illusory vision of decisions and formulations taking place at important moments. In truth, public policies are produced by virtue of continual everyday interactions between various actors (Pires, 2016).

Utilizing the conceptual definition used by Gomide and Pires (2014), an arrangement is "a group of rules, mechanisms and processes which define the particular form that actors and interests are coordinated in the implementation of a specific public policy." Thus, as a complement to the decree, Administrative Rule no 351/MC of 2020 designated Dataprev as the operating agent responsible for acting in the treatment of information designed to generate the payments of the Emergency Aid. The referred to Regulation cites the figure of the paying agent without, however, designating any actor in this role or defining its attributes.

In practice, however, the CEF - which operationalizes the payment of the Programa Bolsa Familia (PBF), and the Unemployment Insurance Program, among others - was responsible for the operationalization of the Emergency Aid, or in other words, it was the paying agent, but its formal designation as such and the definition that various responsibilities of the various units of the MC had executed were pending publication in a normative act.

Within the context of the MC, the Department of the Unified Registry - responsible for the Cadastro Único - and the Department of Information Management - for informational solutions both under the Secretariat of Information Evaluation and Management, together with the Secretariat of Income for Citizenship - responsible for the PBF - and the Sub-secretariat of Information Technology, were the agents responsible for validating the parameters, payment testing, and other acts subsequent to the operationalization of the Emergency Aid.

In this manner, despite the effort made to establish the roles of the actors participating in the implementation of the Emergency Aid through norms, the arrangement in practice extends beyond the contents of the decree and regulation cited above. These norms are the important instruments used to establish several relationships, but they are not necessarily responsible for the creation of the arrangements and also do not reveal the totality of the relationships contained within these arrangements. In other words, seeking to understand and represent the arrangement just through normative acts would present a myopic view of the institutional configuration involved in the production of public policy.

In the case of the Emergency Aid, the conformation of the arrangement was influenced by the preexisting relationships between public agencies, derived from their participation in other public 
policies. This calls attention to the fact that the creation of new institutional arrangements, above all in situations which require quick responses, is not done from scratch and is conditioned by the already existing arrangements in operation within the context of other public policies. The instrumentalization of these relationships will be described in greater detail later in this article.

\section{STRATEGIES TO IDENTIFY THE TARGET PUBLIC}

Informal workers was the term used to designate the target public of this Emergency Aid in its official announcement. However, the identification of citizens belonging to this category is not trivial, due to the various categories of workers created by contemporary legislation.

In reading the text of the law, it is possible to identify inclusive criteria, such as individual microentrepreneurs (MEI), individual contributors to Social Security and informal workers, as well as the exclusionary criteria, such as age, income, having an active formal job, being entitled to social security or assistance benefits, unemployment insurance, or federal cash transfer program, except the PBF. The establishment of these criteria in an objective manner, was of extreme importance in making the implementation of the benefit viable.

As we have seen, in addition to informal workers, the law contemplates several categories of autonomous workers - including individual Social Security contributors - and individual microentrepreneurs (MEI).

In describing the informal worker in item $\mathrm{c}$ of article 2, the law offers two kinds of beneficiaries: those inscribed in the Cadastro Unico, and those who through self-declaration, fulfill the requirements of Subsection IV, which deals with income.

Thus, in a summary manner, we can identify the target public as:

a) Individual micro-entrepreneurs (MEI);

b) Individual Social Security contributors;

c) Those registered in the Cadastro Unico;

d) People not included in the previous hypotheses, through self-declaration.

Some citizens within groups "a", "b" and "c" can be identified in a relatively simple manner, because they possess some kind of administrative record, derived from their relationship with government programs, including social security and assistance programs. The challenge established in implementing the policy would thus be the definition of a way to promote the identification of those citizens who, for unknown reasons, are invisible to social protection policies.

An important reservation related to groups " $a$ " and " $b$ " is that both are fruit of recent measures for the social security formalization of self-employed workers who have instituted the Simplified Social Security Plan or the MEI, generating a generalized expansion of social security coverage (Ansiliero, Costanzi, \& Fernandes, 2020), but are not contemplated by the unemployment insurance program due to the nature of their self-employed work.

As we will see below, based on the responsibility of the $\mathrm{MC}$ for the implementation of requirements for Emergency Aid, a distinct categorization dynamic will be addressed in this section. 


\section{THE IMPLEMENTATION OF EMERGENCY AID}

The implementation of Emergency Aid, with its necessary urgency, was only possible due to the broader context of social policies generated by the MC, including being listed in the Cadastro Unico and in the PBF. So, to understand how preexisting arrangements and instruments have influenced the implementation of Emergency Aid, we will analyze some of its particularities. In this sense, as instruments, we have considered technical and social devices created to promote the relationship, within the arrangements, between public agents and policy beneficiaries (Pires, 2016).

As pointed out by Lotta and Favareto (2016), based on the analysis of the arrangement it is possible to observe central variables (such as the distinguishing of the target public) to understand the way in which the involved actors define themselves and conduct governance, the decision-making process, and degrees of autonomy.

To Pires (2016), the arrangements offer ways to construct the governance model intended to execute the actions, constituting the 'space' for recognizing actors and permitting the construction of an integrated view of public policy.

The operationalization of a new program depends on an apparatus of internal structures and norms, because it is within this arrangement that the program will be absorbed, translated and adapted so that it may be established and adjusted to the agencies and actors who will implement it. The implementation of the MC's Emergency Aid cannot be dissociated from its arrangements and instruments in such a way that "the new is interpreted based on the known" (Lima \& D'Ascenzi, 2013).

The Cadastro Unico, created in 2001 by Decree 3877, was regulated by Decree 6135 of 2007, which characterized it as an "identification instrument and the socioeconomic characterization of Brazilian low-income families" and determined its essential role "in the selection of beneficiaries and the integration of federal government social programs designed to meet the needs of this public."

In this manner, it is possible to identify the Cadastro Unico as the main instrument of the federal government used to identify citizens who, before its creation, were not listed in databases, and also generate socioeconomic information such as family composition, income and other conditions of life.

The Cadastro Único currently contains data on more than 74 million citizens ${ }^{1}$ and is used by various federal programs, with the largest user program being the Bolsa Familia. More than ten years ago, the Cadastro Unico was already observed to be a tool that could be widely used due to its three essential characteristics: broad census information (for the poor population), registry data (with identification and address data) and for its broad identification of information about the conditions of these families' lives (Barros, Carvalho, \& Mendonça, 2009).

The Programa Bolsa Família, created in 2003 by Provisional Measure 132, which was converted into Law 10836 in 2004, is the greatest approximation of Basic Citizenship Income, whose objective is to "provide everyone with a guarantee of the satisfaction of their basic needs," even though the PBF possesses characteristics which distance it from Basic Citizenship Income, including its access requirements, such as family income, and its maintenance requirements, called conditionalities.

\footnotetext{
${ }^{1}$ Retrieved from https://aplicacoes.mds.gov.br/sagi/cecad20/painel03.php
} 
It should be emphasized that the CEF is the operating agent of the Cadastro Unico and the PBF, which demonstrates great synergy between this institution and the MC, reinforcing the thesis of Emergency Aid's taking advantage of preexisting arrangements and instruments.

In addition, it is important to recognize the institution of the Work Group (Grupo de Trabalho) through Administrative Rule 995/GM/MC of 2019, designed to propose measures to improve routines, procedures and qualifications based on the Cadastro Único database, which among other things has permitted the realization of a study, in partnership with Dataprev, "with the goal of analyzing the link of formal income for people registered in the Cadastro Unico" (Grupo de Trabalho, 2019), a routine similar to the verification of the meeting of criteria for the Emergency Aid.

Given this existing context in the MC, the subdivision of the target public materialized in the following manner:

a) PBF beneficiaries;

b) Those registered in the Cadastro Único (who are not Bolsa Familia beneficiaries); and those

c) Outside of the Registry (other citizens not registered in the Cadastro Unico).

This subdivision is important because it characterizes the distinct manner in which access to the Emergency Aid is instrumentalized, and the effects produced by these choices, which make it possible to assimilate the identification dimensions of various target publics based on the experiences of the MC (Lascoumes \& Le Galès, 2012).

The beneficiaries of the PBF were contemplated in an automatic manner, or, in the administrative jargon, 'by default'. This means that all of those who met the Emergency Aid rules received the benefit automatically, without any need for requests or new application. In this manner, verification routines were established for the beneficiaries who met the requisites for granting the Emergency Aid and verifying whether the value of this benefit was greater than that from the PBF. For those who met these criteria, the regular PBF payment was suspended while Emergency Aid payments were made, following the same procedure and respecting the same calendar as the PBF.

For those who are not beneficiaries of the PBF and are registered in the Cadastro Unico, the access format is identical; the difference lies only in relation to the way of payment; in this case through Digital Social Savings Account (Poupança Social Digital) or by a checking or savings account.

Finally, the other citizens not registered in the Cadastro Unico are identified internally as 'Outside of the Registry', there was a need to provide digital requirements on the CEF website or their apps designed for this purpose. ${ }^{2}$

Thus, with the exception of those 'Outside the Registry', all other citizens who were already beneficiaries of the PBF or registered in the Cadastro Unico were included by default in the Emergency Aid recipients. Solutions were developed for the remote registration of those 'Outside the Registry': website, app and telephone center, which demonstrates innovative mobilization to face these challenges and they make it possible to conduct a massive benefit registration to avoid a run on bank branches or units of Social Assistance Reference Centers (CRAS).

${ }^{2}$ Retrieved from https://auxilio.caixa.gov.br/ 
According to the data in Box 1, approximately half of the target public of the Emergency Aid was unknown to the MC, because they were not PBF beneficiaries and were not registered in the Cadastro Unico, which generated additional complexity for the implementation of the policy.

BOX 1

NUMBER OF BENEFICIARIES BY TARGET PUBLIC

\begin{tabular}{lcc}
\multicolumn{1}{c}{ Target public } & Number in millions & Proportion \\
\hline PBF Beneficiaries & 19.2 & $32.5 \%$ \\
Registered in the Cadastro Único & 10.5 & $17.8 \%$ \\
Outside the Registry & 29.3 & $49.7 \%$ \\
Total & 59 & $100 \%$
\end{tabular}

Source: Adapted from the CEF (2020). ${ }^{3}$

Another important aspect to be made concerns the speed in creating and making these instruments available to provide viable access to the Emergency Aid for the 'Outside the Registry' public just five days after the promulgation of the law. Remote requirements in themselves, may already be considered an innovation, illustrative of the growing importance of digital bureaucracy e-government in Brazil and abroad - according to dashboard indicators for federal services, ${ }^{4} 188$ agencies offered 3,554 services through the website, with 1,952 of them being totally digital.

Digital inclusion, however, is still a challenge in Brazil and has proved to be the great enemy of implementing the Emergency Aid and the remotely created instruments, due to problems with access and the difficulty of the registration process itself, even though this was designed to be a simplified experience for the user.

Data from the 2019 ICT Household Survey, conducted by the Regional Center for Studies of the Development of the Information Society, reveal, for example, that only $83 \%$ of urban individuals already accessed the internet, while just $61 \%$ of rural residents have accessed. For internet users, the most utilized device in any of these areas is the cell phone (99\%). It also should be noted, when the survey deals with households with internet access, $75 \%$ of urban households have access and only $51 \%$ of rural households.

Another innovative solution created together with the Emergency Aid is 'Digital Social Savings Account' (Poupança Social Digital), a kind of simplified savings account, exempt from monthly maintenance fees, whose app permits payments and transfers, virtual card transactions, and cash withdrawals without a card in ATM and lotteries. ${ }^{5}$

According to data from the Report of Financial Citizenship (Banco Central do Brasil, 2017), there is a relative stability in the number of people with banking relationships - roughly $86 \%$ of the

\footnotetext{
${ }^{3}$ Retrieved from https://caixanoticias.caixa.gov.br/noticia/20795/auxilio-emergencial-clique-aqui-para-ver-os-ultimos-numeros

${ }^{4}$ Retrieved from http://painelservicos.servicos.gov.br/

${ }^{5}$ Retrieved from http://www.caixa.gov.br/voce/poupanca-e-investimentos/poupanca-social-digital/Paginas/default.aspx
} 
adult population. Of those who do not use banking services, 58\% explained that they do not have banking accounts due to a lack of money or the high cost of maintenance. This same report argues: "The implementation of digital solutions can meet the needs of the portion of the population which considers the maintenance costs of a bank account too high, given that these solutions tend to be lower in cost" (Global Findex [2017 as cited by the Banco Central do Brasil, 2017]).

To Roa (2015), the utilization of the term "financial inclusion" is preferable to looking at the number of people who use banking services, because there can be confusion with people believing this refers to access to services which are offered exclusively by private banks. The author also argues that financial inclusion has three dimensions: access, use and quality.

In effect, the creation of Digital Social Savings Account can be considered a first step in the direction of financial inclusion (access), but it should not be seen as financial inclusion in itself. If the citizen has 'access', but does not use or rarely uses financial services, this is also a problem of financial inclusion. In addition, despite the difficulty in measuring 'quality' it should be taken into consideration: '[...] the diversity and adaptability of the product to customers, the variety and alternatives of financial services, proper regulation and supervision of financial products and services, as well as financial consumer protection policies and financial education.' (Roa, 2015).

In this sense, data from the study The Brazilian's relationship with money ( $O$ brasileiro e sua relação com o dinheiro) (Banco Central do Brasil, 2018) reveals that $60 \%$ of people interviewed most often use cash as a form of payment.

In other words, despite the efforts to digitalize this benefit, what was observed after cash withdrawals were permitted was the opposite of what was desired during the pandemic with crowds of people in lines at CEF branches to withdrawal their Emergency Aid payment. As well thought out as a solution may be, it cannot change peoples' habits and customs by itself, which are based on a history of distrust of banks and the government.

One way to fill this gap and bring large financial institutions closer to the public, according to Gonzalez, Diniz, and Pozzebon (2015), is through partnerships with micro-finance institutions, taking advantage of the "knowledge and skills that "local proximity" provides and thereby creating room for the diversification of microfinance services in ways that maximize their outreach and, we hope, their social impact'. According to the authors, 'to render a more equitable service to society, the financial system has to move toward the former'.

As we have seen, preexisting arrangements have been preponderant in making the implementation of this Emergency Aid viable, because without the expertise of the MC in policies such as the Cadastro Unico and the PBF, which contemplate relationships with the CEF and Dataprev, the complexity of coordinating this new benefit could have made it inviable or may not have led to a satisfactory result in such a short timeframe. In addition, instruments of public action such as the Cadastro Unico and all the routines and flows derived from its operationalization, have shaped the implementation of the Emergency Aid.

In order to make the analysis and processing of standard or remote requirements viable, it was necessary to create a kind of task force to cross-reference the databases, verifying criteria and identifying citizens to be considered in the providing of Emergency Aid. Some details regarding how this task force functioned will be analyzed to contrast with the 'system-level bureaucracy' approach of Bovens and Zouridis (2002). 


\section{STREET, SCREEN AND SYSTEM LEVEL BUREAUCRACY IN THE IMPLEMENTATION OF EMERGENCY AID}

As described above, in the Emergency Aid case, it is possible to observe the inexistence of the 'streetlevel bureaucracy', understood to be those public agents who are on the front line of providing customer service to citizens "and have discretion to exercise authority" (Lipsky, 2019).

From the point of view of Lima and D'Ascenzi (2013), "if having discretion on one hand is indispensable to the development of activities, on the other, its exercise makes it possible to modify public policy in revealing the conceptions of its formulators".

In the opposite way, we were able to observe a high level of competence in the implementation of the Emergency Aid in high and mid-level bureaucrats of MC. This was due to the automatic nature of the known target public analysis, those registered in the Cadastro Único and PBF beneficiaries, and the development of remote customer service tools to handle the registration of the other citizens. From the point of view of Lascoumes and Le Galès (2012), instruments of public action can serve deep transformations and focus attention on analyzing changes in public policies.

Bovens and Zouridis (2002), in describing the way in which the State organizes itself through compliance with the law and providing customer service to citizens, verify an evolution through three levels: 'street-level bureaucracy' (Lipsky, 2019), 'screen-level bureaucracy' and finally, 'system-level bureaucracy'. The main characteristics of these levels are described in Box 2.

BOX 2

COMPARISON OF CHARACTERISTICS

\begin{tabular}{|c|c|c|c|}
\hline & Street-level bureaucracy & Screen-level bureaucracy & System-level bureaucracy \\
\hline Role of ICT & Supportive & Leading & Decisive \\
\hline Functions of ICT & Data registration & $\begin{array}{l}\text { Case assessment and } \\
\text { virtual assembly line }\end{array}$ & $\begin{array}{l}\text { Execution, control, and } \\
\text { external communication }\end{array}$ \\
\hline $\begin{array}{l}\text { Human interference with } \\
\text { individual cases }\end{array}$ & Full & Partial & None \\
\hline Organizational backbone & Case managers & Production managers & Systems designers \\
\hline Organizational boundaries & $\begin{array}{c}\text { Strict, with regard to other } \\
\text { organizations }\end{array}$ & $\begin{array}{l}\text { Strict, both within and } \\
\text { between organizations }\end{array}$ & $\begin{array}{l}\text { Fluid, both within and } \\
\text { between organizations }\end{array}$ \\
\hline Legal regime & $\begin{array}{l}\text { Open, ample discretion, } \\
\text { single legal framework }\end{array}$ & $\begin{array}{l}\text { Detailed, little discretion, } \\
\text { single legal framework }\end{array}$ & $\begin{array}{l}\text { Detailed, no executive } \\
\text { discretion, exchange } \\
\text { between legal domains }\end{array}$ \\
\hline
\end{tabular}

Source: Bovens and Zouridis (2002). 
The initial and most common level of implementation of a public policy occurs on the street level, which according to the conception of Lipsky (2019), has great discretion, even though it is limited by norms and supervision. In addition, it has a certain autonomy, and therefore can generate some inconformity. At this level, ICT is usually used for support, with its main function being to load the data.

Bovens and Zouridis (2002) observe an intermediate level between the street-level bureaucracy and the system level, which they call screen-level bureaucracy. On this level, there is a preponderance of limiting the street-level bureaucrats through the use of software. Unlike the initial stage in which the public agent has a large degree of discretion and autonomy, the screen level is the system which conducts the process, limiting the actions of the agents.

Finally, the most technological implementation level is the system-level bureaucracy. On this level, the citizen interacts directly with the software, eliminating direct human interference. The ICT assumes the role of execution, and situations which are not foreseen in the programming will require system updates to handle them.

According to this logic, the implementation of Emergency Aid is clearly realized by the systemlevel bureaucracy, because through the arrangement established by the $\mathrm{MC}$, it was possible to connect with actors such as Dataprev and CEF, which made the use of instruments such as the CNIS, CPF, and Cadastro Unico databases, among others, to make the necessary verifications of the requirements for conceding the benefit viable.

The argument of Bovens and Zouridis (2002) is that, with the use of ICT, there has been a structural change in various executive public agencies and that due to this, the implementation of the law can be improved with almost all decisions pre-programmed with algorithms and decision trees. The intensive use of technology to implement this Emergency Aid was possible due to the capacities constructed by the quick mobilization of knowledge, institutions and organizations (Skocpol \& Finegold, 1982 as cited by Souza, 2017).

Another characteristic of system-level bureaucracy pointed out by Bovens and Zouridis (2002) is that it is only when the citizen complaint that the specialized employee is put into action - for example, a dispute or an administrative appeal. Within this context, the Emergency Aid still does not have the structure to receive or judge an administrative appeal, as foreseen in article 56 of Law 9784 of 1999, this being one of the gaps that needs to be filled.

Thus, with most cases being treated in a computerized manner, through the cross-referencing of information, the role that remains for street-level bureaucrats is to deal with the remaining cases and the realignment of information with the database based on their interpretation of policy implementation. This realignment is essential so that adjustments and increments in the utilized instruments may be made.

\section{CONCLUSION}

As we have seen, the implementation (still underway) of the Emergency Aid was possible to be made by a group of factors which allowed for a quick response to the challenge of providing income to citizens who cannot work due to restrictive measures and social distancing.

The main highlighted factors are: the leading role of the MC; the previous existence of public action instruments, with databases and information on low income Brazilian families (Cadastro 
Unico); the existence of a conditional cash transfer program (PBF); the existing arrangement for the operationalization of these programs (relationship with the CEF); and the recent arrangement for the improvement of the Cadastro Unico database (relationship with Dataprev).

Other important and innovative factors in the implementation of Emergency Aid have been: the creation of remote request solutions; such as apps, website, and the creation of 'Digital Social Savings Account' (Poupança Social Digital), which have been adopted with the objective of avoiding crowds, collaborating with social distancing measures. However, as we have seen, these items have not been enough by themselves. Due to many beneficiaries having the financial habit of using cash (more than 59 million people), the digital solutions and the concentration on cash withdrawals within a single paying agent, have proved to be insufficient, generating lines and crowds in the CEF branches, which is a reason why solutions could have been thought up, such as utilizing a consortium of banks or including micro-finance institutions, following the argument that 'an inclusive financial system should include many other actors' (Gonzalez, Diniz, \& Pozzebon, 2015). Even so, it is possible to say that Digital Social Savings Account has the potential to be one of the instruments for the financial inclusion of citizens.

The concept of public policy has acquired a new face through the intensive use of information and communications technology firms, as we have verified through the arrangement led by MC, with the participation of CEF and Dataprev, having been the great differential in the implementation of the Emergency Aid.

One concern raised by Bovens and Zouridis (2002), however, is pertinent to this case under analysis. If on one hand, we can celebrate the reduction in arbitrary power in the implementation of rules by street-level bureaucrats, the system-level bureaucracy presents a concern with the possibility that these actors can exercise discretionary power in selecting criteria and constructing information system rules. In other words, independent of their level, these actors wield discretion over people, and their choices can affect the implementation of a public policy.

There are also concerns regarding not only the implementation of Emergency Aid, but also other public policies which are going through a digital transformation, such as: the challenges of the digital and financial inclusion of citizens; the need to open channels where the citizen can appeal decisions as envisaged by the Administrative Process Law; and the strengthening of protest mechanisms, so that it will be possible to point out inconsistencies, difficulties and other situations which have not been previously planned for by these systems.

These mechanisms are vital to realigning system-level bureaucracy and improving the rules of information systems, and promoting a debate which results in the formation of an agenda to discuss legislative increments or reformulations, and also contributes to accountability.

One suggestion for further research on the implementation of Emergency Aid is related to the identification of 'invisible' citizens, those who have been identified just because of the gravity of the pandemic. Finally, public policies, and especially those which seek to provide economic help at times of emergency, need to be compatible with the realities of their citizens. If, in part the digital evolution promoted by the federal government can be celebrated by some, the design of these policies also needs to envision more traditional doors for those who have difficulties in gaining access and for those who are denied access entirely. 


\section{REFERENCES}

Ansiliero, G., Costanzi, R. N., \& Fernandes, A. Z. (2020). Análise descritiva das políticas públicas de inclusão previdenciária dos trabalhadores autônomos: o plano simplificado de previdência social e o microempreendedor individual. (Texto para Discussão no 2546). Rio de Janeiro, RJ: Ipea.

Barros, R. P., Carvalho, M., \& Mendonça, R. (2009). Sobre as utilidades do Cadastro Único. (Texto para Discussão no 1414). Rio de Janeiro, RJ: Ipea.

Banco Central do Brasil. (2017). Relatório de Cidadania Financeira. Brasília, DF. Retrieved from https://www.bcb.gov.br/nor/relcidfin/cap01.html

Banco Central do Brasil. (2018). O brasileiro e sua relação com o dinheiro. Brasília, DF. Retrieved from https://www.bcb.gov.br/content/cedulasemoedas/ pesquisabrasileirodinheiro/Apresentacao_ brasileiro_relacao_dinheiro_2018.pdf

Bovens, M., \& Zouridis, S. (2002). From street-level to system-level bureaucracies: how information and communication technology is transforming administrative discretion and constitutional control. Public Administration Review, 62(2), 174-184.

Centro Regional de Estudos para o Desenvolvimento da Sociedade da Informação. (2019). Domicílios, T.I.C. 2019. São Paulo, SP: Author. Retrieved from https://www.cetic.br/pt/pesquisa/domicilios/ indicadores/

Gomide, A., \& Pires, R. (2014). Capacidades estatais e democracia: arranjos institucionais de politicas públicas. Brasília, DF: Ipea.

Gonzalez, L., Diniz, E. H., \& Pozzebon, M. (2015). The value of proximity finance: how the traditional banking system can contribute to microfinance. Innovations: Technology, Governance, Globalization, 10(1-2), 125-137.
Grupo de Trabalho para Aperfeiçoamento do Processo de Averiguação Cadastral do Cadastro Único para Programas Sociais do Governo Federal. (2019). Relatório final. Brasília, DF. Retrieved from https://aplicacoes.mds.gov.br/sagirmps/ ferramentas/docs/Relato $\%$ CC $\% 81$ rio\%20GT\%20 cadastro\%20\%C3\%BAnico.pdf

Howlett, M., Ramesh, M., \& Perl, A. (2013). Política pública: seus ciclos e subsistemas: uma abordagem integral. São Paulo, SP: Campus.

Lascoumes, P., \& Le Galès, P. (2012). A ação pública abordada pelos seus instrumentos. Revista Pós Ciências Sociais, 9(18). Retrieved from http://www. periodicoseletronicos.ufma.br/index.php/rpcsoc/ article/view/1331/1048

Lima, L. L., \& D’Ascenzi, L. (2013). Implementação de políticas públicas: perspectivas analíticas. Revista de sociologia e política, 21(48), 101-110.

Lipsky, M. (2019). Burocracia em nível de rua: dilemas do indivíduo nos serviços públicos. Brasília, DF: Enap.

Lotta, G., \& Favareto, A. (2016). Desafios da integração nos novos arranjos institucionais de políticas públicas no Brasil. Revista de Sociologia e Política, 24(57), 49-65.

Pires, R. (2016). Intersetorialidade, arranjos institucionais e instrumentos da ação pública. Cadernos de Estudos Desenvolvimento Social em Debate, 26, 67-80.

Roa, M. J. (2015). Financial inclusion in Latin America and the Caribbean: access, usage and quality. México, DF: Center for Latin America Monetary Studies.

Souza, C. (2017). Modernização do Estado e construção de capacidade burocrática para a implementação de políticas federalizadas. Revista de Administração Pública, 51(1), 27-45. Retrieved from https://doi.org/10.1590/0034-7612150933

\section{Bruno Baranda Cardoso}

https://orcid.org/0000-0001-6122-5092

Master's Student in Public Policy and Development at the Institute of Applied Economic Research (IPEA); Specialist in Public Management at the National School of Public Administration (ENAP); Director of the Department of Training and Dissemination of the Secretariat of Information Evaluation and Management of the Ministry of Citizenship (DFD/SAGI/MC).E-mail: brunobaranda@gmail.com 